\title{
PRODUCENT AUDIOWIZUALNY - POJĘCIE I POZYCJA PRAWNA
}

\section{Abstract \\ THE AUDIOVISUAL PRODUCER - CONCEPT AND LEGAL POSITION}

The production of audiovisual forms is organisationally and economically complicated. The issues "inside" audiovisual work, as well as the huge costs of production and distribution, or the potential income from their dissemination in various fields of exploitation, may cause conflicts between authors, producers, and users. That is the reason why balancing these interests requires a rational intervention of the legislator. The aim of the considerations is to find an answer to the question about an audiovisual producer and their legal position in the light of legal acts and practice. There are very few opinions on this subject and the article aims to fill the existing cognitive gap. The research problem is presented by law regulations, using the formal and dogmatic method.

Keywords: audiovisual producer, audiovisual work, author's economic rights

\section{Wprowadzenie}

Podjęte w artykule rozważania koncentrują się wokół sfery audiowizualnej, mającej duże znaczenie gospodarcze. O tym, że nie są to kwestie proste, świadczą liczne wypowiedzi piśmiennictwa (Gębicka, 2013, s. 51 i nast.; Zabłocki, 2013, s. 5 i nast.), realizacja utworu audiowizualnego jest bowiem szczególnie skomplikowanym przypadkiem twórczości zespołowej (Świętczak, 2019, s. 1053; Wojciechowska, 1999, s. 53; Kakareko, 2019, s. 32). Przyczynkiem do powstania niniejszego artykułu było wejście w życie w dniu 9 listopada 2018 r. ustawy o finansowym wspieraniu produkcji audiowizualnej (Dz.U. z 2021 r., poz. 198, dalej jako ustawa o zachętach lub ustawa z 2018 r.). W uzasadnieniu do projektu ustawy czytamy o „przedsiębiorstwach 
działających w zakresie produkcji audiowizualnej (Russel, 2018, s. 2). W Polsce od roku 2000 działa Krajowa Izba Producentów Audiowizualnych (KIPA)ํ. Stowarzyszenie Filmowców Polskich stworzyło wyodrębnioną jednostkę organizacyjną do spraw zbiorowego zarządu prawami autorskimi i pokrewnymi, pod nazwą Związek Autorów i Producentów Audiowizualnych (ZAPA)². Od roku 2018 działa również Polska Gildia Producentów³ ${ }^{3}$ zrzeszająca producentów audiowizualnych.

Ustawa o zachętach zdefiniowała produkcję audiowizualną jako „zespół czynności twórczych, organizacyjnych, ekonomicznych, prawnych i technicznych prowadzących do wytworzenia utworu audiowizualnego", można by się zatem spodziewać, iż zdefiniuje również pojęcie „producent audiowizualny” jako podmiot ją prowadzący, ale zawiera ona definicję legalną pojęcia „producent utworu audiowizualnego". Uzasadnione wobec tego jest pytanie, czy można postawić znak równości między pojęciem "producent audiowizualny” a „producent utworu audiowizualnego"? Artykuł zapełnić ma istniejącą lukę badawczą, ponieważ pojęcie „producent audiowizualny” nie występuje w tekstach aktów normatywnych, lecz posługuje się nim praktyka oraz niektórzy przedstawiciele doktryny - w polskim piśmiennictwie Piotr Ślęzak. Warto zaznaczyć, że poglądy tego autora ewoluowały. Początkowo przyjmował on pogląd, iż producentem audiowizualnym jest podmiot, który jest równocześnie producentem utworu kinematograficznego i producentem wideogramu (Ślęzak, 2007, s. 516). Następnie autor ten był zdania, iż producentem audiowizualnym jest podmiot będący producentem utworu audiowizualnego, a niekiedy producentem wideogramu (Ślęzak, 2012, s. 316). Pogląd, iż producent audiowizualny to podmiot, który zajmuje się produkcją utworu audiowizualnego oraz wideogramów, cytowany autor wypowiada ponownie w komentarzu do ustawy o prawie autorskim pod swoją redakcją (Ślęzak, 2017, s. 466).

Celem głównym opracowania jest zatem poszukiwanie odpowiedzi na pytanie, jak należy - w świetle obowiązujących przepisów prawa i praktyki obrotu - rozumieć pojęcie producenta audiowizualnego oraz jaka jest jego pozycja prawna. Osiągnięcie tak postawionego celu badawczego wymagało sformułowania następujących pytań badawczych: w odniesieniu do jakiego przedmiotu chronionego można mówić producencie - czy jest to jedynie utwór audiowizualny czy także wideogram oraz jak przepisy polskiego prawa charakteryzują pojęcie producenta oraz przysługujące mu prawa? Założonemu celowi artykułu została podporządkowana jego systematyka.

W artykule zostanie dokonana analiza przepisów prawa i wypowiedzi piśmiennictwa - z zastosowaniem metody wykładni tekstu prawnego wedle koncepcji

1 Członkami jej są firmy producenckie specjalizujące się w produkcji filmowej, telewizyjnej i reklamowej, http://kipa.pl/.

2 Zob. https://www.zapa.org.pl/. ZAPA jest członkiem międzynarodowego stowarzyszenia producentów AGICOA, której celem jest zarządzanie prawami autorskimi i pokrewnymi, https:// www.agicoa.org/english/about/bylaws_2020.pdf.

3 Zob. http://gildiaproducentow.pl/. 
derywacyjnej - metodą leksykalną. Analizie poddano stosowne przepisy ustawy o zachętach oraz ustawy z dnia 4 lutego 1994 roku o prawie autorskim i prawach pokrewnych (t.j. Dz.U. z 2019 r., poz. 1231 ze zm., dalej jako ustawa o prawie autorskim lub ustawa prawnoautorska), ustawy z dnia 29 grudnia 1992 roku o radiofonii i telewizji (t.j. Dz.U. z 2020 r., poz. 804 ze zm.), jak również ustawy z dnia 30 czerwca 2005 roku o kinematografii (t.j. Dz.U. z 2021 r., poz. 257). Analiza aktów wewnętrznych, regulujących działanie organizacji producenckich także służy poszukiwaniu odpowiedzi na zadane pytanie badawcze. Przedmiot artykułu wymagał wykorzystania stosunkowo szerokiej bazy źródłowej w postaci wskazanych aktów prawnych, jak również odwołania się do literatury przedmiotu ${ }^{4}$.

\section{Utwór audiowizualny}

Utworem audiowizualnym, w rozumieniu z ustawy z 2018 r., jest „utwór złożony z serii następujących po sobie obrazów z dźwiękiem lub bez dźwięku, utrwalonych na nośniku umożliwiającym wielokrotne odtwarzanie, wywołujących wrażenie ruchu i składających się na oryginalną całość wyrażającą akcję lub treść w indywidualnej formie, zrealizowany $\mathrm{w}$ formie filmu fabularnego, dokumentalnego lub animowanego albo serialu fabularnego, dokumentalnego lub animowanego, niezależnie od pola eksploatacji, o którym mowa w przepisach ustawy o prawie autorskim i prawach pokrewnych". Definicja ta opiera się na definicji filmu, określonej $\mathrm{w}$ ustawie o kinematografii ${ }^{5}$, ma jednak ma szerszy zakres przedmiotowy, przepisy ustawy obejmują bowiem możliwość finansowania nie tylko filmów fabularnych, których pierwszym polem eksploatacji jest kino, ale także różnego rodzaju utworów audiowizualnych, niezależnie od pierwszego pola eksploatacji.

Jako że podstawowym założeniem ustawy o zachętach miała być możliwość uzyskania wsparcia finansowego na produkcję audiowizualną lub świadczenie

4 Literatura z zakresu prawa autorskiego, przywoływana w opracowaniu, jest bogata, a omówienia ustawy o kinematografii są bardzo nieliczne (zob. Ożóg, 2009, s. 111; Jakimiec, 2017, s. 99). Nie ma też jeszcze wypowiedzi naukowych na temat ustawy o zachętach, co uzasadnia prześledzenie przebiegu procesu ustawodawczego: https://legislacja.rcl.gov.pl/projekt/12293603.

Zgodnie $\mathrm{z}$ tą definicją filmem jest utwór dowolnej długości, w tym utwór dokumentalny lub animowany, złożony z serii następujących po sobie obrazów z dźwiękiem lub bez dźwięku, utrwalonych na jakimkolwiek nośniku umożliwiającym wielokrotne odtwarzanie, wywołujących wrażenie ruchu i składających się na oryginalną całość, wyrażającą akcję (treść) w indywidualnej formie, a ponadto, $\mathrm{z}$ wyjątkiem utworów dokumentalnych $\mathrm{i}$ animowanych, przewidziany do wyświetlania w kinie jako pierwszym polu eksploatacji w rozumieniu przepisów o prawie autorskim i prawach pokrewnych. Wskazać jednak trzeba, iż w ustawie z dnia 31 marca 2020 r. o zmianie ustawy o szczególnych rozwiązaniach związanych z zapobieganiem, przeciwdziałaniem i zwalczaniem COVID-19, innych chorób zakaźnych oraz wywołanych nimi sytuacji kryzysowych (Dz.U. z 2020 r., poz. 568) przewidziano zmianę tej definicji, wskazując, iż filmem jest również utwór, który z powodu okoliczności niezawinionych nie został wyświetlony w kinie. 
usługi na rzecz produkcji audiowizualnej, zawiera ona również ograniczenia przedmiotowe. Wyłączone jest przyznawanie wsparcia finansowego na: rejestrację wykonań utworów słownych, słowno-muzycznych, muzycznych lub pantomimicznych; rejestrację zdarzeń z życia politycznego, społecznego, kulturalnego, religijnego, gospodarczego lub sportowego; rejestrację sporządzaną na rzecz nauki, nauczania, techniki, reklamy, promocji, informacji lub instruktażu; rejestrację sporządzaną na użytek wewnętrzny Kościołów i innych związków wyznaniowych; rejestrację zdarzeń z życia prywatnego oraz rejestrację treści pornograficznych. Dalsze ograniczenia przedmiotowe wynikają z przepisów wykonawczych ${ }^{6}$, które wskazują rodzaje utworów audiowizualnych, na które może zostać udzielone wsparcie, wraz z określeniem ich minimalnej długości i budżetu przez wskazanie minimalnej wysokości polskich wydatków kwalifikowalnych, co z założenia kieruje mechanizm wsparcia finansowego do średnich i dużych produkcji audiowizualnych.

Czy zasadne było zatem wprowadzanie definicji legalnej pojęcia utworu audiowizualnego, wobec faktu, że jest ona, zdaniem autorki, wystarczająco dookreślona przez orzecznictwo i praktykę prawa autorskiego? Definicja taka powinna także korespondować z pojęciem utworu w ustawie o prawie autorskim ${ }^{7}$, utwory audiowizualne są bowiem wymienione jako jeden z rodzajów utworów w art. 1 pkt 9 ustawy o prawie autorskim ${ }^{8}$. Ze względu na specyfikę i szczególnie skomplikowany charakter stosunków zawiązujących się przy ich tworzeniu i eksploatacji ustawodawca zdecydował się poświęcić im zespół przepisów wyodrębnionych w 6 rozdziale ustawy, które zostaną scharakteryzowane przy okazji omawiania praw i obowiązków producenta.

Wobec braku definicji ustawowej, Piotr Ślęzak (2012, s. 437 i nast.) zaproponował, aby utworem audiowizualnym nazywać materiały o charakterze audiowizualnym, spełniające kryteria objęcia ich ochroną autorskoprawną.

Charakter audiowizualny mają te materiały, które składają się z obrazów: wyrażonych jako sekwencja; sprawiających w czasie odtwarzania wrażenie ruchu; udźwiękowionych lub nieudźwiękowionych oraz utrwalonych na dowolnym nośniku. Cechami pozwalającymi na zakwalifikowanie ich jako utwór są działalność twórcza o indywidualnym charakterze oraz ustalenie (uzewnętrznienie).

6 Zob. Rozporządzenie Ministra Kultury i Dziedzictwa Narodowego z dnia 11 lutego 2019 r. w sprawie szczegółowego wykazu polskich kosztów kwalifikowalnych, parametrów utworów audiowizualnych oraz dokumentów związanych z przyznawaniem wsparcia finansowego na produkcję audiowizualną przez Polski Instytut Sztuki Filmowej (Dz.U. z 2019 r., poz. 309).

7 Na okoliczność braku uzgodnienia definicji w ramach systemu prawa wskazuje Stowarzyszenie Kreatywna Polska (2017), podkreślając niebezpieczeństwo objęcia nią produkcji, które nie powinny otrzymać wsparcia. Maciej Dydo (2018, s. 2) stwierdza, że ustawa nie będzie częścią systemu prawa cywilnego i nie ingeruje w system ochrony przewidziany przepisami ustawy o prawie autorskim.

8 Przykładowo utworami audiowizualnymi, chronionymi przez ZAPA, są: filmy i seriale fabularne, filmy i seriale dokumentalne, filmy i seriale animowane, filmy i seriale lalkowe, telenowele i sitcomy, telenowele paradokumentalne, teatry telewizji, dokumenty fabularyzowane, fabularyzowane rekonstrukcje sądowe, scripted reality, animacje 3D. 
Przesłanka oryginalności zostaje spełniona, gdy powstaje nowy wytwór intelektu człowieka, a indywidualny charakter utworu oznacza, iż na jego kształt musi mieć wpływ osobowość twórcy. Trzeba przy tym dodać, że dla stwierdzenia oryginalności materiału audiowizualnego należy wskazać w nim elementy przesądzające o nowatorstwie w dziedzinie formy (Ślęzak, 2012, s. 128). Warunkiem powstania utworu jest jego ustalenie (uzewnętrznienie) w jakiejkolwiek postaci, która umożliwia percepcję przez osoby inne niż twórca. Wskazać również trzeba, iż ustalenie utworu najczęściej jest związane z jego uzewnętrznieniem przybierającym formę trwałą - jest to utrwalenie. Gdyby utożsamiać ustalenie utworu z jego utrwaleniem - także w postaci zapisu cyfrowego - prowadzi to do dalszych konsekwencji. Każdy utwór audiowizualny będzie korzystać z równoległej ochrony prawami pokrewnymi jako wideogram, a gdyby ustalenie miało być jednocześnie utrwaleniem, to jego wersja ostateczna staje się odpowiednikiem oryginalnego egzemplarza utworu.

Pojęcie wideogramu obejmuje pierwsze utrwalenie sekwencji ruchomych obrazów, które może spełniać cechy utworu audiowizualnego. W przypadku utworu audiowizualnego dochodzi zatem do zbiegu uprawnień do całości dobra niematerialnego. Z jednej strony producent nabywa w sposób pochodny prawo autorskie do dzieła audiowizualnego, a z drugiej, równolegle, odpowiednie, słabsze prawo pokrewne powstaje ex lege na rzecz tego samego podmiotu. Istota wideogramu polega na dokonaniu pierwszej rejestracji materiału wizualnego lub audiowizualnego jakąkolwiek techniką (Klafkowska-Waśniowska, 2011, s. 115) dla objęcia ochroną wielowymiarowego wysiłku podmiotu doprowadzającego do utrwalenia „sekwencji ruchomych obrazów”. Udzielona ochrona ma zapobiegać przejmowaniu utrwalonych obrazów, co ma służyć ochronie gospodarczych interesów producenta, umożliwiając mu amortyzację poniesionych kosztów produkcji danego nośnika przez zagwarantowanie wyłączności na określone sposoby jego eksploatacji. $\mathrm{W}$ odniesieniu do tego samego przedmiotu ochrony istnieją uprawnienia o różnym zakresie - twórców audiowizualnych, producenta utworu audiowizualnego oraz producenta wideogramu, co może rodzić nieuniknione konflikty przy eksploatacji utworów.

\section{Producent}

Nie do przecenienia jest rola producenta $\mathrm{w}$ tworzeniu utworu audiowizualnego. Mimo że producenci funkcjonowali w obrocie od lat 90., do 2004 roku nie było to pojęcie zdefiniowane $\mathrm{w}$ polskim prawie. $\mathrm{W}$ prawie autorskim $\mathrm{w}$ art. 15 ustanowiono jedynie domniemanie, zgodnie z którym za producenta uważa się osobę, której nazwisko lub nazwę umieszczono w tym charakterze na przedmiotach, na których utwór utrwalono lub podano do publicznej wiadomości w jakikolwiek sposób z związku z rozpowszechnieniem utworu. Brzmienie komentowanego przepisu stanowi jednak źródło licznych wątpliwości. Nie bardzo wiadomo, które 
konkretnie podmioty ustawodawca miał w tym wypadku na myśli, wyraźnie bowiem brakuje tu dopełnienia; o producencie można wszak mówić tylko w odniesieniu do konkretnego dobra (Ślęzak, 2012, s. 317; Czajka, 2010, s. 160).

Jak stanowi art. 94 ust. 3 prawa autorskiego, domniemywa się, że producentem fonogramu lub wideogramu jest osoba, pod której nazwiskiem lub firmą (nazwą) fonogram lub wideogram został po raz pierwszy sporządzony.

W rozumieniu ustawy o zachętach przez pojęcie "producenta utworu audiowizualnego” należy rozumieć „przedsiębiorcę, który podejmuje inicjatywę dotyczącą produkcji audiowizualnej, organizuje, prowadzi produkcję audiowizualną i ponosi odpowiedzialność za tę produkcję oraz nabywa autorskie prawa majątkowe do utworu audiowizualnego". Przyjrzyjmy się zatem poszczególnym elementom tej definicji. W polskim ustawodawstwie przez pojęciem przedsiębiorcy rozumie się - zgodnie z ustawą z dnia 6 marca 2018 r. Prawo przedsiębiorców (Dz.U. z 2021 r., poz. 162) - osobę fizyczną, osobę prawną lub jednostkę organizacyjną niebędącą osobą prawną, której odrębna ustawa przyznaje zdolność prawną, wykonująca działalność gospodarczą. Ustawa o zachętach przyjęła jednak szerszą definicję przedsiębiorcy, jaka jest przewidziana w prawie europejskim ${ }^{9}$. Ustawa wprowadziła także ograniczenia podmiotowe, które mają na celu skierowanie środków publicznych w postaci wsparcia finansowego do podmiotów, których zasadniczą działalnością jest produkcja audiowizualna filmów lub seriali. Stąd między innymi wyklucza się możliwość otrzymania wsparcia finansowego przez podmioty, które jednocześnie prowadzą działalność jako dostawcy audiowizualnych usług medialnych, podmioty rozprowadzające programy drogą kablową, satelitarną lub za pośrednictwem systemu teleinformatycznego.

Poszukiwanie wyjaśnień dla części definicji dotyczącej „podejmowania inicjatywy, organizowania, prowadzenia i ponoszenia odpowiedzialności za produkcję audiowizualną" wymaga odwołania się do innych aktów prawnych. I tak, mocą ustawy z dnia 2 kwietnia 2004 r. o zmianie ustawy o radiofonii i telewizji (Dz.U. z 2004 r. Nr 91, poz. 874) wprowadzono do niej definicję producenta, wskazując, iż jest to osoba fizyczna lub osoba prawna, lub jednostka organizacyjna, o której mowa $\mathrm{w}$ art. $33^{1} \S 1$ kodeksu cywilnego ${ }^{10}$, która podejmuje inicjatywę, faktycznie organizuje i ponosi odpowiedzialność za kreatywny, organizacyjny i finansowy

9 Przedsiębiorca to podmiot, o którym mowa w art. 1 załącznika I do Rozporządzenia Komisji z dnia 17 czerwca 2014 r. nr 651/2014 uznającego niektóre rodzaje pomocy za zgodne z rynkiem wewnętrznym w zastosowaniu art. 107 i 108 traktatu (Dz. Urz. UE. L nr 187). Przez pojęcie przedsiębiorstwa rozumie się podmiot prowadzący działalność gospodarczą bez względu na jego formę prawną i zalicza się tu w szczególności osoby prowadzące działalność na własny rachunek oraz firmy rodzinne zajmujące się rzemiosłem lub inną działalnością, a także spółki lub stowarzyszenia prowadzące regularną działalność gospodarczą.

10 Zgodnie z ustawą z dnia 23 kwietnia 1964 r. - Kodeks cywilny (Dz.U. z 2020 r., poz. 1740 ze zm.) są to jednostki organizacyjne, niebędące osobami prawnymi, którym ustawa przyznaje zdolność prawną. Mogą to być spółki handlowe osobowe oraz stowarzyszenia niezarejestrowane (Czarny-Drożdżejko, 2014, s. 85 i nast.). 
proces produkcji utworu audiowizualnego. Producentem w myśl komentowanego przepisu może być każdy podmiot stosunków cywilnoprawnych, a czynności, które przesądzają o jego statusie, dzieli się na trzy aspekty: inicjatywę, organizację i odpowiedzialność w odniesieniu do procesu produkcji utworu audiowizualnego w wymiarze kreatywnym, organizacyjnym i finansowym. Stanisław Piątek wyraża pogląd, iż ta definicja nie ma samodzielnego znaczenia, lecz jedynie uzupełnia definicję pojęcia producent niezależny $\mathrm{z}$ art. 4 pkt 26 ustawy o radiofonii i telewizji. Pomaga nam jednak w wyjaśnieniu pozycji prawnej producenta, wskazując, iż w rozumieniu ustawy o radiofonii nie jest nim producent wideogramu. W odniesieniu do komentowanego przepisu Elżbieta Czarny-Drożdżejko wyraziła pogląd, iż producentem może być każdy ze względu na rozwój technologii i łatwość tworzenia utworów audiowizualnych. Gdy jednak efekty pierwszego utrwalenia sekwencji ruchomych obrazów nie są utworem audiowizualnym, osoba taka nie będzie producentem w rozumieniu ustawy (Czarny-Drożdżejko, 2014, s. 86).

Pojęcie producenta [filmu - przyp. A.G.H.] pojawia się też w ustawie o kinematografii. Zgodnie z jej art. 5 pkt 6, producentem filmu jest osoba fizyczna, osoba prawna lub jednostka organizacyjna, o której mowa w art. $33^{1} \$ 1$ kodeksu cywilnego, która podejmuje inicjatywę, faktycznie organizuje, prowadzi i ponosi odpowiedzialność za kreatywny, organizacyjny i finansowy proces produkcji filmu. Wskazuje się w piśmiennictwie (Ożóg, 2009, s. 127), iż gdybyśmy cechy charakteryzujące producenta czytali w koniunkcji, to wiedzielibyśmy, kto jest producentem. Będzie to - w modelowym ujęciu - ktoś, kto podejmuje inicjatywę, faktycznie organizuje, prowadzi i ponosi odpowiedzialność za kreatywny, organizacyjny i finansowy proces produkcji filmu. Przy czym, jak słusznie konstatuje autor, niezmiernie rzadko będziemy mieć do czynienia z sytuacją, kiedy będzie to jeden podmiot. Typowa jest natomiast sytuacja, gdy podmiotów takich jest więcej - funkcje przydzielone producentowi są rozdzielone pomiędzy różne osoby. W takim przypadku zasadne byłoby wskazanie jednej z tych funkcji jako szczególnie istotnej, przesądzającej o istocie działalności producenta. Podążając zatem za Marcinem Ożogiem, musimy zapytać, które cechy sprawiają, że dana osoba jest producentem. Czy akcent powinien padać na aspekt kapitałowy - a zatem czy ma to być osoba, która ponosi ryzyko finansowe związane z produkcją filmu, finansowaniem go, a następnie eksploatacją w obrocie rynkowym, czy też raczej uznamy, że będzie to osoba, która faktycznie organizuje i prowadzi proces produkcji? W wypowiedziach sądów widzimy tendencję do przyporządkowania okoliczności przemawiających za uznaniem danego podmiotu za producenta, bez wskazania cechy głównej. W wyroku Sądu Apelacyjnego w Krakowie z dnia 14 stycznia 2003 r. mowa o tym, iż o kwalifikacji osoby producenta przesądzają trzy cechy. Zdaniem Sądu Apelacyjnego producentem jest osoba, która ponosi ciężar finansowy kosztów wytworzenia filmu i ryzyko jego eksploatacji; organizuje techniczne i rzeczowe przesłanki produkcji filmu; zawiera we własnym imieniu i na własny rachunek umowę o stworzenie utworu audiowizualnego. 
Marcin Ożóg występuje z propozycją - wspartą odwołaniem do art. 4 ust. 2 pkt 1 i 2 ustawy o kinematografii, w którym mowa o wielkości środków finansowych zaangażowanych w produkcję filmu - by przy definiowaniu pojęcia producenta położyć nacisk na przesłankę ponoszenia odpowiedzialności. Z tym poglądem koresponduje stanowisko Michała Zabłockiego (2013, s. 44), zgodnie z którym obowiązki producenta ponoszącego odpowiedzialność materialną (ekonomiczną) i niematerialną (artystyczną i moralną) zwykle wiążą się z ciężką pracą koncepcyjno-organizacyjną, często twórczą i wymagającą nieustannego zaangażowania. Polski ustawodawca przyjął $\mathrm{w}$ prawie autorskim, że producentowi przysługują do utworu audiowizualnego uprawnienia majątkowe, a nie osobiste. Nie wymienia go jako współtwórcy w przepisie art. 69 prawa autorskiego, przy czym praktyka umów zawieranych w przemyśle filmowym wskazuje na twórczy charakter działań producenta (Krüger, 2012). Przyjęcie przez polskiego ustawodawcę modelu producenta-inwestora, odmawiające domniemania jego twórczości z art. 69, nie wyklucza udziału producenta $\mathrm{w}$ tym gronie. Fakt, iż producent nie korzysta $\mathrm{z}$ domniemań wskazanych w art. 69, oznacza konieczność przeprowadzenia dowodu na okoliczność, że miał twórczy wkład w powstanie utworu audiowizualnego. Jeżeli by jednak przyjąć, iż producent prowadzi - co do zasady - działalność o charakterze organizacyjno-finansowym, to nie ma w utworze audiowizualnym wkładów o twórczym charakterze, przy czym autorka zdaje sobie sprawę z dyskusyjności tego poglądu. De lege ferenda należałoby postulować, by ustawodawca zauważył ten element twórczy, który dostrzega praktyka i obce porządki prawne ${ }^{11}$.

Dalszy człon definicji producenta w ustawie o zachętach mówi o „nabywaniu autorskich praw majątkowych do utworu audiowizualnego", co uprawnia do dokonania charakterystyki art. 70 oraz przepisów art. 71 i 87 prawa autorskiego.

Rozpoczynając rozważania na temat majątkowych uprawnień producenta, trzeba wskazać iż ustawodawstwo polskie ewoluowało w tym zakresie. W art. 70 ust. 1 prawa autorskiego w wersji pierwotnej majątkowe prawa autorskie do utworu audiowizualnego przysługiwały producentowi. Producent był właścicielem praw autorskich do utworu audiowizualnego jako całości, od chwili jego powstania, ale nie przysługiwały mu z mocy ustawy prawa majątkowe do poszczególnych wkładów. Celem tej regulacji było stworzenie jasnej i stabilnej sytuacji prawnej, co pozwalało uniknąć sytuacji spornych, negatywnie wpływających na eksploatację utworu (Klafkowska-Waśniowska, 2011, s. 115). Artykuł 70 w brzmieniu obecnym, nadanym ustawą z dnia 9 czerwca 2000 r. o zmianie ustawy o prawie autorskim i prawach pokrewnych (Dz.U. Nr 53, poz. 637), mocno osłabia pozycję prawną producenta. $\mathrm{W}$ art. 70 ust. 1 ustawodawca ustanowił wzruszalne domniemanie prawne, zgodnie z którym producent utworu audiowizualnego nabywa na mocy umowy o stworzenie utworu albo umowy o wykorzystanie już istniejącego

11 Patrycja Fingas (2015, s. 180) jest zdania, że rozwiązania faworyzujące producentów audiowizualnych są podstawą potęgi kinematograficznej przemysłu amerykańskiego. 
utworu wyłączne prawa majątkowe do eksploatacji tych utworów w ramach utworu audiowizualnego jako całości. Aby obalić to domniemanie, należy wykazać, iż umowa między producentem a twórcami inaczej określa rozkład majątkowych praw autorskich. Dopóki domniemanie nie zostanie obalone, należy przyjmować, że to producent, a nie twórcy poszczególnych utworów, jest uprawniony do eksploatacji utworu audiowizualnego jako całości.

Producent nabywa uprawnienie do korzystania z utworu audiowizualnego oraz rozporządzania utworem audiowizualnym na podstawie umów na wszystkich polach eksploatacji, na jakich utwór może być eksploatowany w ramach utworu audiowizualnego jako całości, wynagrodzenia za korzystanie z utworu audiowizualnego przez osoby trzecie oraz decydowania o wykonywaniu autorskich praw zależnych.

Jak stanowi przepis art. 71 prawa autorskiego, producent może także bez zgody twórców utworu audiowizualnego dokonywać tłumaczeń na różne wersje językowe.

Przepis art. 87 stanowi, że - z braku odmiennych uregulowań - zawarcie przez artystę wykonawcę $\mathrm{z}$ producentem utworu audiowizualnego umowy o współudział w realizacji utworu audiowizualnego przenosi na producenta prawa do rozporządzania i korzystania $\mathrm{z}$ wykonania, w ramach tego utworu audiowizualnego, na wszystkich znanych w chwili zawarcia umowy polach eksploatacji. Widać tutaj wyraźnie uprzywilejowanie producenta, a ratio legis tego przepisu jest ułatwienie producentowi korzystania z utworu (Grzybczyk, 2017, s. 614; Gołaszewska, 2019, s. 1400).

Skoro zostały przedstawione regulacje ustawowe, można teraz zbadać, czy i jak definiuje producenta praktyka obrotu. Statut Stowarzyszenia Filmowców Polskich wskazuje, że stowarzyszenie zrzesza twórców oraz osoby fizyczne i prawne, które podlegają ochronie praw autorskich i pokrewnych w zakresie utworów audiowizualnych. Producenci, zgłaszając się do ZAPA, powierzają autorskie prawa majątkowe do wyprodukowanych utworów oraz prawa pokrewne do wideogramów. Jak stanowi regulamin ZAPA, powierzenie praw w zarząd dotyczy zarówno zezwalania na korzystanie z utworów oraz przedmiotów praw pokrewnych wymagające udzielenia licencji, jak i korzystania, które - zgodnie z przepisami ustawy o prawie autorskim - wymaga tylko ustalenia wysokości należnego wynagrodzenia i warunków płatności. Powierzenie praw w zakresie majątkowych praw autorskich i praw pokrewnych dotyczy dochodzenia roszczeń w odniesieniu do korzystania z utworów oraz przedmiotów praw pokrewnych, w zakresie pól eksploatacji objętych umową.

Członkami zwyczajnymi KIPA mogą być podmioty prowadzące działalność gospodarczą w zakresie produkcji utworów audiowizualnych, aktywnie uczestniczące bądź wspomagające produkcję audiowizualną, a także organizatorzy innych audiowizualnych form artystycznych, takich jak festiwale, spektakle, aplikacje mobilne czy gry wideo. Przepis $\$ 7$ lit. d regulaminu KIPA do podstawowych zadań zalicza podejmowanie działań mających na celu ochronę autorskich praw majątkowych i praw pokrewnych producentów audiowizualnych. 
Widać tutaj zatem, iż praktyka obrotu przez pojęcie producenta audiowizualnego rozumie zarówno producenta utworu audiowizualnego, jak i producenta wideogramu.

\section{Wnioski i podsumowanie}

Odpowiadając na pytania zadane na wstępie niniejszych rozważań, przede wszystkim należy stwierdzić, że omówione przepisy prawa nie udzielają jasnej odpowiedzi na pytanie, kim jest producent audiowizualny.

W szczególności nie definiuje tego pojęcia prawo autorskie, ograniczając się do wprowadzenia określonych domniemań - w art. 15 - w odniesieniu do utworu audiowizualnego oraz - w art. 94 - w odniesieniu do wideogramów. Przywołani przez autorkę $\mathrm{w}$ toku rozważań przedstawiciele doktryny prawa autorskiego na ogół są zdania, że status producenta według ustawy o prawie autorskim należałoby przyznać osobie organizującej stworzenie utworu audiowizualnego, decydującej o jego kształcie, przy czym o statusie tym nie powinien decydować sam fakt finansowania produkcji. Podkreślić jednak należy, że takie rozumienie producenta nie jest z kolei spójne z ustawą o kinematografii ani z ustawą o radiofonii i telewizji, jak również nie do końca odpowiada przyjętej w branży praktyce ani rzeczywistości dotyczącej znaczenia twórczej roli producenta $\mathrm{w}$ filmie czy w tych produkcjach telewizyjnych, które mogłyby korzystać $\mathrm{z}$ dofinansowania przewidzianego w ustawie o zachętach. Zdaniem Marcina Ożoga (2009, s. 126) ustawa o kinematografii dotycząca zagadnienia produkcji form audiowizualnych jest aktem najbardziej predestynowanym biorąc pod uwagę całość systemu prawa - by stać się źródłem definicji pojęć z tym związanych, podział zaś uregulowań dotyczących filmu na publiczno- i prywatnoprawne ma charakter umowny. Trzeba bowiem wskazać, iż definicja producenta utworu audiowizualnego z ustawy o zachętach, pomimo zaliczenia tego aktu do prawa publicznego, zawiera również - jak się wydaje - aspekty prywatnoprawne poprzez odwołanie do klasycznych pojęć prawa autorskiego. W ocenie autorki nie można przy tym ocenić pozytywnie nieuwzględnienia przez ustawodawcę postulatów środowiska producenckiego, by definicja producenta odwoływała się i nawiązywała do już obowiązujących aktów prawnych. Wszak system prawa powinien być spójny, a ustawodawca racjonalny. Należy także wskazać w tym miejscu, że zgodność sposobu rozumienia pojęcia producenta mogłaby w znacznym stopniu umożliwić producentom sprawniejsze działanie w obrocie prawnym.

Dokonana na potrzeby niniejszego artykułu analiza aktów wewnętrznych organizacji zrzeszających producentów audiowizualnych uprawnia do stwierdzenia, iż nie definiują one pojęcia "producent audiowizualny”, które jest raczej stosowane przez przedstawicieli doktryny i utrwalone w praktyce obrotu.

Poszukując odpowiedzi na pytanie, jakie prawa przysługują producentowi, trzeba wskazać, iż większość przytoczonych definicji akcentuje wykonywane przez 
niego pewne czynności, którymi są: podjęcie inicjatywy dotyczącej produkcji audiowizualnej wraz z organizacją tego procesu, zapewnienie środków do realizacji produkcji i ponoszenie odpowiedzialności za proces produkcji. Zgodnie z terminologią z zakresu prawa cywilnego producentowi przysługują uprawnienia majątkowe, czyli uprawnienie do korzystania $\mathrm{z}$ utworu audiowizualnego oraz rozporządzanie nim na podstawie umów na wszystkich polach eksploatacji oraz do wynagrodzenia za korzystanie $\mathrm{z}$ utworu audiowizualnego przez osoby trzecie. Terminologii autorskoprawnej używają w swoich uregulowaniach wewnętrznych również zrzeszenia producentów.

Aby zaproponować definicję „producenta audiowizualnego", trzeba odpowiedzieć na pytanie, jaki jest przedmiot chroniony, do którego odnosi się to pojęcie. Przepisy ustawy o radiofonii, kinematografii oraz ustawa o zachętach mówią w tym kontekście o producencie utworu audiowizualnego. Ustawa o zachętach wprowadza nawet definicję legalną utworu audiowizualnego, postulowaną od dłuższego czasu przez doktrynę prawa autorskiego, przy czym - zdaniem autorki niesłusznie - jedynie na potrzeby tej ustawy. Twórcom nie przyświecał najwyraźniej zamysł ujednolicenia sytemu prawa cywilnego w zakresie utworu audiowizualnego i jego relacji do wideogramu, co jednakowoż wpływa na ustalenie pozycji i praw uprawnionych podmiotów. Wideogramy - określone jako „rejestracja wykonań utworów słownych, słowno-muzycznych, muzycznych lub pantomimicznych" - zostały wyłączone spod zakresu przedmiotowego zarówno w ustawie o kinematografii, jak i w ustawie o zachętach. Można przypuszczać, że był to celowy zabieg służący ograniczeniu katalogu podmiotów ubiegających się o dofinansowanie. Obok producenta utworu audiowizualnego producent wideogramu - jako podmiot uprawniony z tytułu eksploatacji - jest wskazany jedynie w przepisach ustawy o prawie autorskim. Praktyka obrotu, jak dowodzi analiza aktów wewnętrznych, wskazuje jednak, iż producent audiowizualny jest podmiotem będącym producentem utworu audiowizualnego, ale również podmiotem praw pokrewnych do wideogramu będącego utworem audiowizualnym.

Dokonując rekapitulacji powyższych ustaleń trzeba wskazać, iż w rozumieniu przepisów prawa publicznego producentem audiowizualnym jest podmiot będący producentem utworu audiowizualnego. Natomiast w myśl przepisów prawa autorskiego oraz praktyki obrotu, producent audiowizualny jest producentem utworu audiowizualnego lub producentem wideogramu będącego utworem audiowizualnym. W ocenie autorki należy przyjąć szersze rozumienie tego pojęcia - $\mathrm{w}$ ten sposób producent audiowizualny to producent utworu audiowizualnego, ale również producent wideogramu.

Kończąc rozważania, trzeba podkreślić zamierzenie autorki dotyczące przyszłych badań rozwijających wątek producenta audiowizualnego zarówno w ujęciu teoretycznym i praktycznym, jak i w kontekście prawa międzynarodowego. Autorka w pełni podziela bowiem pogląd (Ożóg, 2009, s. 154), iż ustanowienie wsparcia dla producentów interaktywnej zawartości audiowizualnej - innej niż utwór 
audiowizualny - umożliwiłoby lepszy rozwój społeczeństwa informacyjnego w Polsce.

\section{Bibliografia}

Czajka D. (2010). Ochrona praw twórców i producentów. Prawo autorskie i prawa pokrewne. Warszawa: Europejska Wyższa Szkoła Prawa i Administracji.

Czarny-Drożdżejko E. (2014). Ustawa o radiofonii i telewizji. Komentarz. Warszawa: Wydawnictwo LexisNexis.

Dydo M. (2018). Raport z konsultacji projektu ustawy o finansowym wspieraniu produkcji audiowizualnej, Warszawa, https://legislacja.rcl.gov.pl/docs//2/12293603/12402434/1240243 5/dokument351537.pdf (dostęp: 7.08.2020).

Fingas P. (2015). Pozycja prawna producenta utworu audiowizualnego na gruncie amerykańskiego i polskiego prawa autorskiego. Analiza porównawcza. „Zeszyty Naukowe Prawa Własności Intelektualnej Uniwersytetu Śląskiego", 3, s. 88-181.

Gębicka E. (2013). Problemy zarządzania procesem produkcji filmu w otoczeniu nowych mediów i w realiach polskiej kinematografii. „Zarządzanie Mediami”, 1, s. 51-62.

Gołaszewska A. (2019). Komentarz do art. 94 [w:] M. Machała, R. Sarbiński (red.), Prawo autorskie i prawa pokrewne. Komentarz. Warszawa: Wolters Kluwer.

Grzybczyk K. (2017). Komentarz do art. 94 [w:] P. Ślęzak (red.), Ustawa o prawie autorskim i prawach pokrewnych. Komentarz. Warszawa: Wydawnictwo C.H. Beck.

Jakimiec D. (2017). Ustawa o kinematografii. Komentarz. Warszawa: Rozpisani.pl.

Kakareko K. (2019). Status prawny twórców utworów filmowych. Poznań: Silva Rerum.

Klafkowska-Waśniowska K. (2011). Producent utworu audiowizualnego a producent wideogramu [w:] K. Lewandowski (red.), Utwór audiowizualny. Zakres pojęcia i ochrony prawnej. Poznań: Wyższa Szkoła Umiejętności Społecznych w Poznaniu.

Krüger Z. (2012). Producent filmowy - twórca czy inwestor? „Business and Beauty”, 9, http:// www.businessandbeauty.pl/producent-filmowy-tworca-czy-inwestor/ (dostęp: 21.08.2020).

Ożóg M. (2009). Podstawowe pojęcia ustawy z 30.06.2005 r. o kinematografii. „Prace Instytutu Prawa Własności Intelektualnej Uniwersytetu Jagiellońskiego", 104, s. 110-154.

Piątek S. (red.) (2014). Ustawa o radiofonii i telewizji. Komentarz. Warszawa: Wydawnictwo C.H. Beck.

Russel P. (2018). Ocena skutków regulacji zawartych w rządowym projekcie ustawy o finansowym wsparciu produkcji audiowizualnej (druk sejmowy nr 2794), Warszawa, http://www. sejm.gov.pl/Sejm8.nsf/opinieBAS.xsp?nr=2794 (dostęp: 20.07.2020).

Rządowe Centrum Legislacji (2016). Przebieg prac nad projektem ustawy o finansowym wspieraniu produkcji audiowizualnej, https://legislacja.rcl.gov.pl/projekt/12293603 (dostęp: 12.07.2020).

Stowarzyszenie Kreatywna Polska (2017). Stanowisko w sprawie projektu ustawy o wspieraniu produkcji audiowizualnej, https://legislacja.rcl.gov.pl/docs//2/12293603/12402407/124024 10/dokument270869.pdf (dostęp: 13.08.2020).

Ślęzak P. (2007). Pojęcie producenta audiowizualnego. „Prace Instytutu Prawa Własności Intelektualnej Uniwersytetu Jagiellońskiego", 100, s. 515-529.

Ślęzak P. (2012). Umowy w zakresie współczesnych sztuk wizualnych. Warszawa: LEX, Wolters Kluwer. 
Ślęzak P. (2017). Komentarz do art. 94 [w:] P. Ślęzak (red.), Ustawa o prawie autorskim i prawach pokrewnych. Komentarz. Warszawa: Wydawnictwo C.H. Beck.

Świętczak M. (2019). Komentarz do art. 69 [w:] M. Machała, R. Sarbiński (red.), Prawo autorskie i prawa pokrewne. Komentarz. Warszawa: Wolters Kluwer.

Wojciechowska A. (1999). Autorskie prawa osobiste twórców dzieła audiowizualnego. Kraków: Uniwersytet Jagielloński, Zakamycze.

Zabłocki M. (2013). Organizacja produkcji filmu fabularnego w Polsce. Warszawa: Wydawnictwo Wojciech Marzec.

http://gildiaproducentow.pl/ (dostęp: 8.08.2020).

http://kipa.pl/ (dostęp: 7.07.2020).

https://www.zapa.org.pl (dostęp: 15.05.2020).

\section{Wykorzystane akty normatywne}

Rozporządzenie z dnia 17 czerwca 2014 r. uznające niektóre rodzaje pomocy za zgodne z rynkiem wewnętrznym w zastosowaniu art. 107 i 108 traktatu z dnia 17 czerwca 2014 r., Dz. Urz. UE. L 187.

Ustawa z dnia 23 kwietnia 1964 - Kodeks cywilny, Dz.U. z 1964 r. Nr 16, poz. 93 ze zm., t.j. Dz.U. z 2020 r., poz. 1740 ze zm.

Ustawa z dnia 9 czerwca 2000 r. o zmianie ustawy o prawie autorskim i prawach pokrewnych, Dz.U. Nr 53, poz. 637.

Ustawa z dnia 29 grudnia 1992 r. o radiofonii i telewizji, Dz.U. z 1993 r. Nr 7, poz. 34, t.j. Dz.U. z 2020 r., poz. 804 ze zm.

Ustawa z dnia 4 lutego 1994 r. o prawie autorskim i prawach pokrewnych, Dz.U. z 1994 r. Nr 24, poz. 83 ze zm., t.j. Dz.U. z 2019 r., poz. 1231 ze zm.

Ustawa z dnia 9 czerwca 2000 r. o zmianie ustawy o prawie autorskim i prawach pokrewnych, Dz.U. Nr 53, poz. 637.

Ustawa z dnia 2 kwietnia 2004 r. o zmianie ustawy o radiofonii i telewizji, Dz.U. z 2004 r. Nr 91, poz. 874.

Ustawa z dnia 30 czerwca 2005 r. o kinematografii, Dz.U. z 2005 r. Nr 132, poz. 1111 ze zm., t.j. Dz.U. z 2021 r., poz. 257.

Ustawa z dnia 6 marca 2018 r. Prawo przedsiębiorców, Dz.U. z 2018 r., poz. 646 ze zm., t.j. Dz.U. z 2021 r., poz. 162.

Ustawa $\mathrm{z}$ dnia 9 listopada 2018 r. o finansowym wspieraniu produkcji audiowizualnej, Dz.U. z 2019, poz. 50 ze zm., t.j. Dz.U. z 2021 r., poz. 198.

Ustawa z dnia 31 marca 2020 r. o zmianie ustawy o szczególnych rozwiązaniach związanych z zapobieganiem, przeciwdziałaniem i zwalczaniem COVID-19, innych chorób zakaźnych oraz wywołanych nimi sytuacji kryzysowych, Dz.U. z 2020 r., poz. 568.

By-laws of the Association for the International Collective Management of Audiovisual Works (AGICOA), 14 May 1991, https://www.agicoa.org/english/about/bylaws_2020.pdf (dostęp: 7.08.2020).

Regulamin działania wyodrębnionej jednostki organizacyjnej ds. zbiorowego zarządu ZAPA Stowarzyszenia Filmowców Polskich z dnia 19 grudnia 1995 r. ze zm., https://www.zapa. org.pl/aktualnosci,19,43, Regulamin.html (dostęp: 7.08.2020).

Rozporządzenie Ministra Kultury i Dziedzictwa Narodowego z dnia 11 lutego 2019 r. w sprawie szczegółowego wykazu polskich kosztów kwalifikowalnych, parametrów utworów audiowizualnych oraz dokumentów związanych z przyznawaniem wsparcia finansowego na produkcję audiowizualną przez Polski Instytut Sztuki Filmowej, Dz.U. z 2019 r., poz. 309. 
Statut Krajowej Izby Producentów Audiowizualnych z 19 listopada 2015 r., http://kipa.pl/statut/ (dostęp: 7.08.2020).

Statut Stowarzyszenia Filmowców Polskich z 10 maja 2000 r. ze zm., https://www.zapa.org.pl/_ vault/_files/42/796f1dacafdf72e961f96fd194ca6c52.pdf (dostęp: 7.08.2020).

\section{Wykorzystane orzeczenia}

Wyrok Sądu Apelacyjnego w Krakowie z dnia 14 stycznia 2003 r., I ACa 1137/02, „Transformacje Prawa Prywatnego" 2003, nr 3, s. 117. 